\title{
Influence of Magnesium Addition on Mechanical Properties and Microstructure of Al-Cu-Mg Alloy
}

\author{
Sani A Salihu, Aliyu Isah, Polycarp Evarastics \\ Department of Metallurgical and Materials Engineering Technology, Waziri Umaru Federal polytechnic, Birnin \\ Kebbi, Kebbi State, Nigeria.
}

\begin{abstract}
The influence of $\mathrm{Mg}$ addition on mechanical properties and microstructure of $\mathrm{Al}-\mathrm{Cu}-\mathrm{Mg}$ alloy was investigated. Cast $\mathrm{Al}-\mathrm{Cu}-\mathrm{Mg}$ alloys have widely been used in aircraft, aerospace, industrial and architectural applications for their good mechanical properties, high strength-to-weight ratio. An intensive study of these cast aluminium family has been found in many literature as a source for enhancing the mechanical properties and microstructure of aluminium alloys. The main objective of this paper was to investigate the effect of magnesium on mechanical properties and microstructural changes of $\mathrm{Al}_{4} \mathrm{Cu}$ alloys. The modifications of $\mathrm{Al}_{4} \mathrm{Cu}$ by adding $\mathrm{Mg}$ of 0.5 to $2.5 \%$ in the interval of $0.5 \%$ mixing with stirrer and casted by gravity die casting, subsequently the specimens were subjected T6 type heat treatment for $6 \mathrm{hr}$ at $180^{\circ} \mathrm{C}$. The effect of $\mathrm{Mg}$ and ageing on microstructure was studied by using optical microscope. The mechanical properties such as tensile strength and hardness were studied using universal tensile testing machine and Brinell hardness tester respectively. It was observed that the tensile strength and hardness increased with increase of percentage of $M g$. The addition of $2.5 \% \mathrm{Mg}$ increases the tensile strength by $69.9 \%$ while hardness increased by $22 \%$. Samples that were aged showed that with addition of $1 \%$ of $\mathrm{Mg}$ had effect on grain refinement and mechanical properties of the alloy because of smaller grain size.
\end{abstract}

Keywords: $\mathrm{Al}-\mathrm{Cu}-\mathrm{Mg}$ alloy, Grain size, Hardness, Tensile strength, microstructure.

\subsection{Introduction}

Aluminium alloys are used in automotive, aerospace, construction, and shipbuilding industry because of their combination of high strength, low density, durability, machinability, availability and the cost is also very attractive compared to competing materials (Mondolfo). Because of the excellent strength vs. density ratio, formability and corrosion resistance, $\mathrm{Al}-\mathrm{Cu}-\mathrm{Mg}$ alloys are potential candidates for a numerous industrial applications (Yang, Hunt, Edmonds, 1993). Even though, due to their high specific strength, they are mainly considered as a substitute of iron-based on mentioned metallic system are now being considered and developed (Zluticanin, et al (2003).

Magnesium increases the strength and hardness of the alloys, but especially in castings, this is accompanied by a decrease in ductility and impact resistance (Garg, Howe, 1992). Standard industrial aluminium-copper alloys solidify with the formation of a dendrite structure, however, a tendency to form with a globular structure at higher copper contents was reported (Muhammad Riaz Khan, et al, 2008).

This paper present an investigation that was done on the as-cast structure of $\mathrm{Al}-\mathrm{Cu}-\mathrm{Mg}$ system over a wide range of magnesium contents in order to know the effect of magnesium content on the microstructure and mechanical properties of $\mathrm{Al}-\mathrm{Cu}-\mathrm{Mg}$ alloys. Depending upon the alloy composition $(\mathrm{Cu}$ contents and $\mathrm{Cu} / \mathrm{Mg}$ ratio), different phase distributions and consequently different $\mathrm{Al}-\mathrm{Cu}-\mathrm{Mg}$ alloys having a copper content of $4 \mathrm{wt} \%$ and $\mathrm{Cu} / \mathrm{Mg}$ ratio 4.2.5, 4: 2, 4: 1.5, 4:1, 4:0.5 respectively, is done by quantitative microstructure analysis and hardness and tensile strength determination. The materials investigated consist of aluminium as a primary constituent and copper is the major addition with magnesium $0-2.5 \mathrm{wt} \%$ varied in steps of $0.5 \mathrm{wt} \%$.

\subsection{Methodology}

\subsection{Alloy Preparation}

The material used for this work was purchased in Kaduna from aluminium construction company ( NOCACO) and were prepared according to the normal process (melting $\mathrm{Al}$ plus $\mathrm{Mg}$ ). The compositions were melted in an electrical resistance furnace, using graphite crucible. The molten metal was poured into permanent cylindrical die of diameter $25 \mathrm{~mm}$ with $200 \mathrm{~mm}$ long. Die was preheated to $185^{\circ} \mathrm{C}$. The composition of the alloy was determined using Optical Emission Spectrometer at Nigerian Foundry plc.

The experimental work was divided in two phases. The first phase consists of specimen preparation such as melting, casting and ageing heat treatment of samples with different compositions in the aluminium-coppermagnesium ( $\mathrm{Al}-\mathrm{Cu}-\mathrm{Mg})$ system. The second phase includes mechanical characterization like ultimate tensile strength, yield strength, hardness and microstructural studies using optical microscope of as-cast and heat treated samples. 


\subsection{Mechanical Tests}

Mechanical Tests such as Tensile and Hardness were conducted according to ASTM standards. In the present study, the tensile test was conducted to using a standard 30 ton capacity Servo-hydraulic universal testing machine of model UTES-30. The test was carried out at room temperature and in accordance with ASTM A370 standards. Three specimens were tested and average values of the Ultimate Tensile Strength are reported. In the present study, hardness of the specimens was measured by using a standard Brinell hardness testing machine. The hardness test was conducted in accordance with ASTM E10 standards. Six readings were taken for each specimen at different locations to circumvent the possible effect of any alloying element segregation and the average value was considered.

\subsection{Results and Discussion}

The Chemical composition test was carried by Optical Emission spectrometer. Table 1 shows the chemical composition of the developed alloys.

Table 1. Chemical composition of developed Al-Cu-Mg alloys

\begin{tabular}{|c|c|c|c|c|c|c|c|c|c|}
\hline $\begin{array}{ll}\text { Mg } & \text { content } \\
(\%) & \end{array}$ & Type of alloy & $\% \mathrm{Cu}$ & $\% \mathrm{Mg}$ & $\% \mathrm{Fe}$ & $\% \mathrm{Si}$ & $\% \mathrm{Mn}$ & $\% \mathrm{Ti}$ & $\begin{array}{l}\% \\
\mathrm{Zn}\end{array}$ & $\begin{array}{l}\% \\
\text { Al }\end{array}$ \\
\hline 0.00 & $\mathrm{AlCu}_{4} \mathrm{Mg}$ & 4.25 & 0.00 & 0.26 & 0.24 & 0.3 & 0.02 & 0.04 & Bal. \\
\hline 0.50 & $\mathrm{AlCu}_{4} \mathrm{Mg}$ & 4.30 & 0.79 & 0.26 & 0.24 & 0.3 & 0.04 & 0.04 & Bal. \\
\hline 1.00 & $\mathrm{AlCu}_{4} \mathrm{Mg}$ & 4.38 & 0.98 & 0.28 & 0.24 & 0.4 & 0.05 & 0.06 & Bal. \\
\hline 1.50 & $\mathrm{AlCu}_{4} \mathrm{Mg}$ & 4.30 & 1.50 & 0.28 & 0.24 & 0.4 & 0.05 & 0.06 & Bal. \\
\hline 2.00 & $\mathrm{AlCu}_{4} \mathrm{Mg}$ & 4.75 & 1.97 & 0.28 & 0.24 & 0.4 & 0.05 & 0.06 & Bal. \\
\hline 2.50 & $\mathrm{AlCu}_{4} \mathrm{Mg}$ & 4.89 & 2.28 & 0.30 & 0.24 & 0.40 & 0.06 & 0.07 & Bal. \\
\hline
\end{tabular}

Table 2. Mechanical properties of developed Al-Cu-Mg alloys

\begin{tabular}{|c|c|c|c|c|c|c|}
\hline $\begin{array}{l}\text { Mg } \\
\text { content } \\
(\%)\end{array}$ & $\begin{array}{l}\text { Type of } \\
\text { alloy }\end{array}$ & $\begin{array}{l}\text { Tensile } \\
\text { strength } \\
\text { (MPa) As } \\
\text { cast alloy }\end{array}$ & $\begin{array}{l}\text { Tensile strength } \\
\text { (MPa) Heat } \\
\text { treated alloy }\end{array}$ & $\begin{array}{l}\text { Yield } \\
\text { strength } \\
\text { (Mpa). As } \\
\text { cast alloy }\end{array}$ & $\begin{array}{l}\text { Hardness } \\
\text { (BHN) As } \\
\text { cast alloy }\end{array}$ & $\begin{array}{l}\text { Hardness } \\
\text { (BHN) Heat } \\
\text { treated alloy }\end{array}$ \\
\hline 0.00 & $\mathrm{AlCu}_{4} \mathrm{Mg}$ & 101.89 & 110.80 & 86.69 & 72.20 & 90.20 \\
\hline 0.50 & $\mathrm{AlCu}_{4} \mathrm{Mg}$ & 105.80 & 134.02 & 92.40 & 73.50 & 91.00 \\
\hline 1.00 & $\mathrm{AlCu}_{4} \mathrm{Mg}$ & 120.04 & 139.50 & 100.60 & 90.20 & 92.00 \\
\hline 1.50 & $\mathrm{AlCu}_{4} \mathrm{Mg}$ & 122.50 & 219.40 & 103.20 & 90.80 & 96.80 \\
\hline 2.00 & $\mathrm{AlCu}_{4} \mathrm{Mg}$ & 159.98 & 140.10 & 125.60 & 90.90 & 90.00 \\
\hline 2.50 & $\mathrm{AlCu}_{4} \mathrm{Mg}$ & 172.06 & 110.05 & 136.00 & 94.20 & 92.00 \\
\hline
\end{tabular}

\subsection{Mechanical properties}

The mechanical properties of the different form of samples with various compositions were studied. The tensile properties of the $\mathrm{Al}$ alloys under investigation were determined using universal tensile testing machine as observed in Table 3 and Figures 1 and 2. It was clear that the tensile strength increases with increase of $\% \mathrm{Mg}$. the hardness values are shown in Table 2. As we can observed, that the hardness behaviour of these materials follow the same trend as the tensile strength, where the change in the chemical composition of the alloy causes changes in the structure that are reflected on the hardness and the tensile strength. By increasing the content of magnesium, hardness and the tensile strength also increases with reference to as-cast condition. Fig.1 and Fig 2 shows that for $1 \%$ of magnesium the alloy exhibits maximum strength in terms of UTS and hardness this is may be due to smaller the grain size. Figure 3 shows standard schematic tensile test sample as stipulated by ASM 


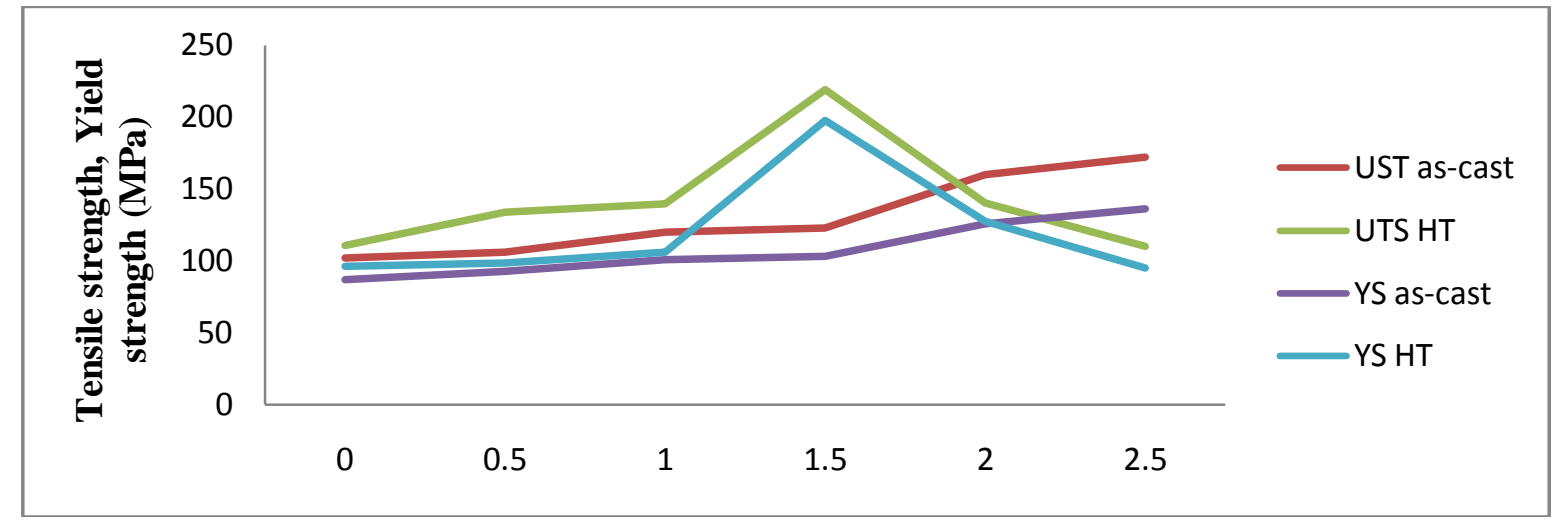

Fig. 1. Tensile properties versus Mg content

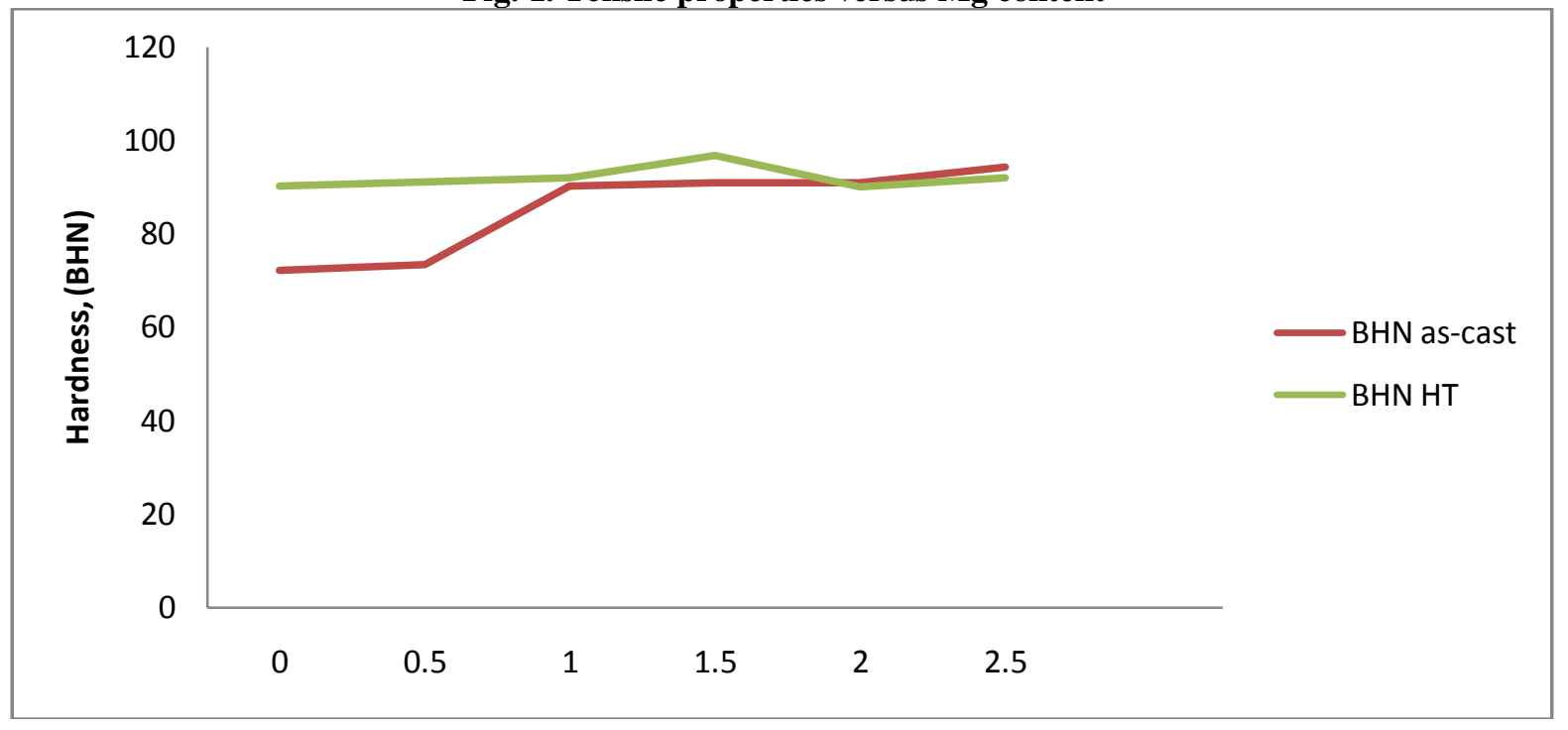

Figure 2. Hardness versus magnesium content

The constituents formed in the alloys containing only one or more of copper, magnesium etc, are soluble ones. In $\mathrm{AlCu}_{4} \mathrm{Mg} 0.5$ alloy in which the copper; magnesium ratio is in the range 8:1 to 4:1 the main hardening agents are $\mathrm{Al}_{2} \mathrm{Cu}$ and $\mathrm{Al}_{2} \mathrm{CuMg}$ both are active. In $\mathrm{AlCu}_{4} \mathrm{Mg} 1, \mathrm{AlCu}_{4} \mathrm{Mg} 1.5, \mathrm{AlCu}_{4} \mathrm{Mg} 2$ and $\mathrm{AlCu}_{4} \mathrm{Mg} 2.5$ alloys in which the $\mathrm{Cu} / \mathrm{Mg}$ ratio is in the range between 4:1 and 1:0.5 $\mathrm{Al}_{2} \mathrm{CuMg}$ controls the properties.

\subsection{Microstructural analysis}

Optical microscope was used for microstructural studies of the as-cast and heat treated alloys of $\mathrm{Al}-\mathrm{Cu}-\mathrm{Mg}$ alloys. The specimens were grinded with emery paper of different sizes, polished with polishing agent and etched with Keller's reagent for metallographic analysis.

The copper content in the standard AlCuMg alloys was up to 4 wt $\%$ that represents the maximum solid solubility of copper in aluminium at the eutectic temperature of $548^{\circ} \mathrm{C}$. As we have observed that these investigated AlCuMg alloys have dendrite-cellular structures. Figure $4(\mathrm{a}, \mathrm{b})$, shows the micrographs in as-cast condition consisting of dendrites of aluminium solid solution as the primary phase, with a eutectic mixture filling the interdendritic spaces. The second phase can be an intermetallic compounds that contain aluminium with one or more alloying elements $\left(\mathrm{Al}_{2} \mathrm{Cu}\right.$ and $\left.\mathrm{Al}_{2} \mathrm{CuMg}\right)$ intermetallic compounds that do not necessarily contain aluminium $\left(\mathrm{Mg}_{2} \mathrm{Cu}\right.$ or $\left.\mathrm{MgCu}_{2}\right)$ or alloying elements, such as copper or magnesium, depending on the composition of the alloy. This was in agreement with Girisha and Sharma (2012) who concluded that Figures 4 and 5 show the microstructure of the prepared as-cast and heat treated alloy consisting of eutectic grey phase and Aluminium-rich phase, while the eutectic surrounding has a mixture of copper and magnesium phases. The dark regions showed intermetallics like $\mathrm{Al}_{2} \mathrm{Cu}$ and $\mathrm{Al}_{2} \mathrm{CuMg}(\varepsilon)$. 
a)

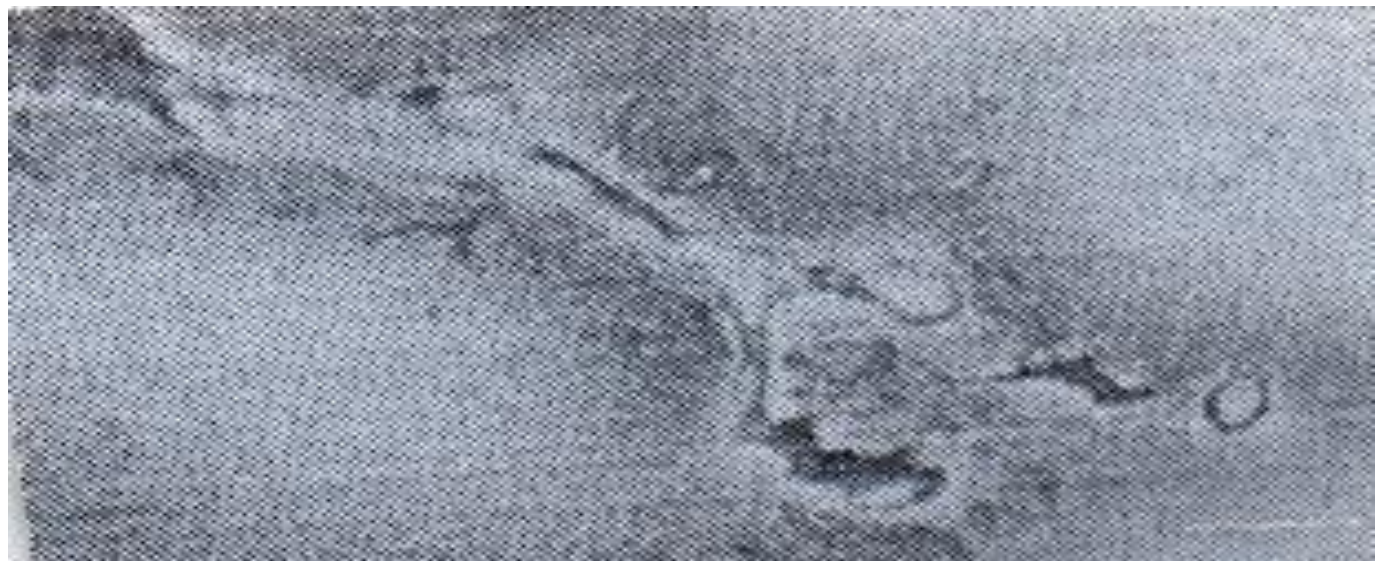

b)

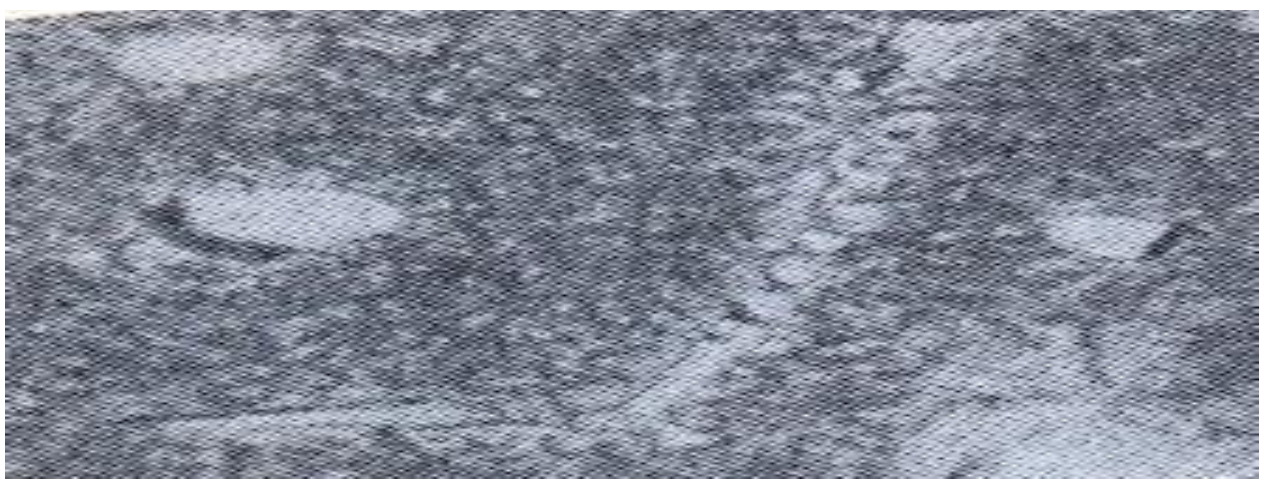

c)

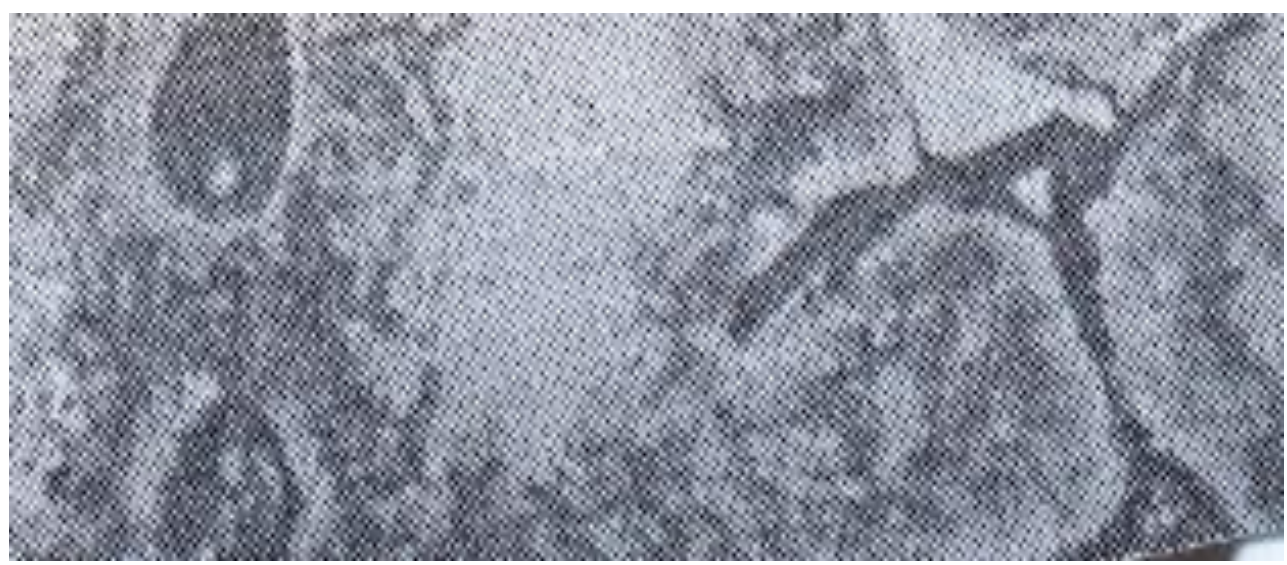

Figure 4. Micrographs of as-cast samples of $\mathrm{Al}_{4} \mathrm{Cu}$ alloy: a) $1 \% \mathrm{Mg}$, b) $2 \% \mathrm{Mg}$, c) $2.5 \% \mathrm{Mg}$ 
a)

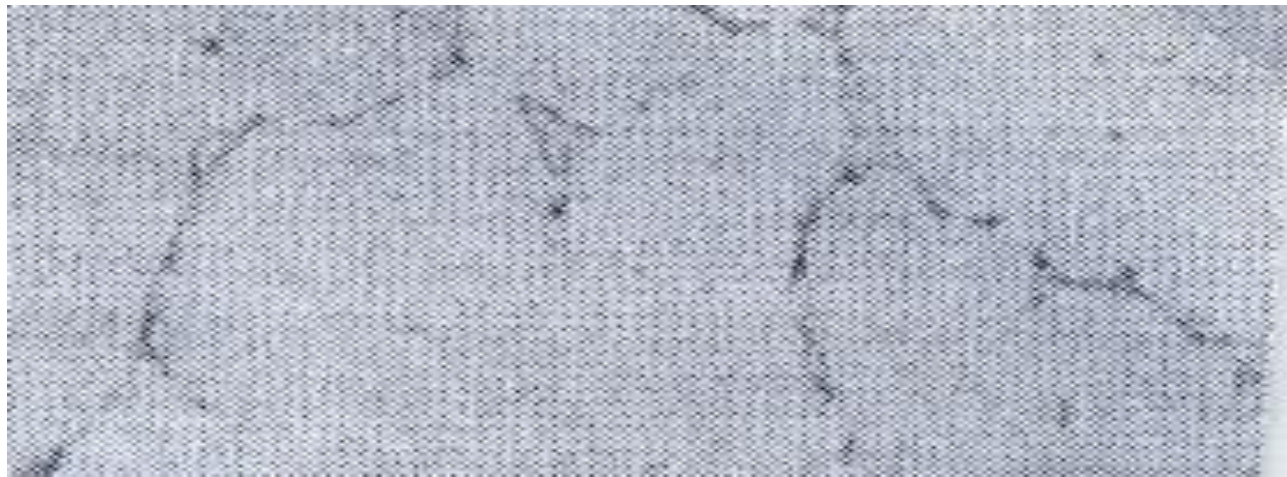

b)

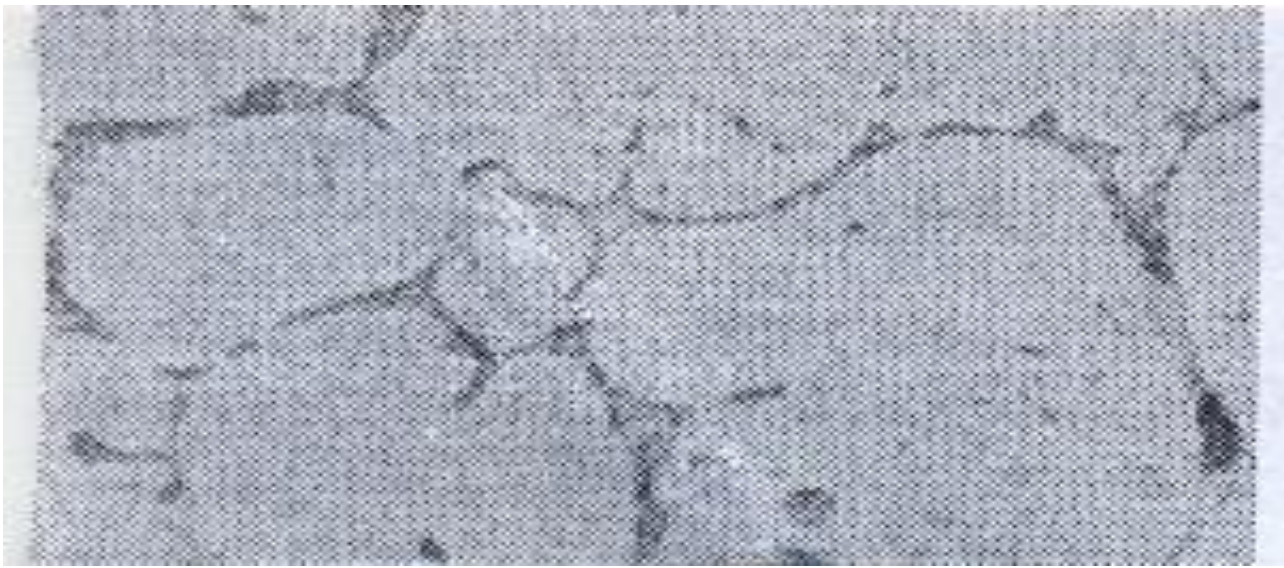

c)

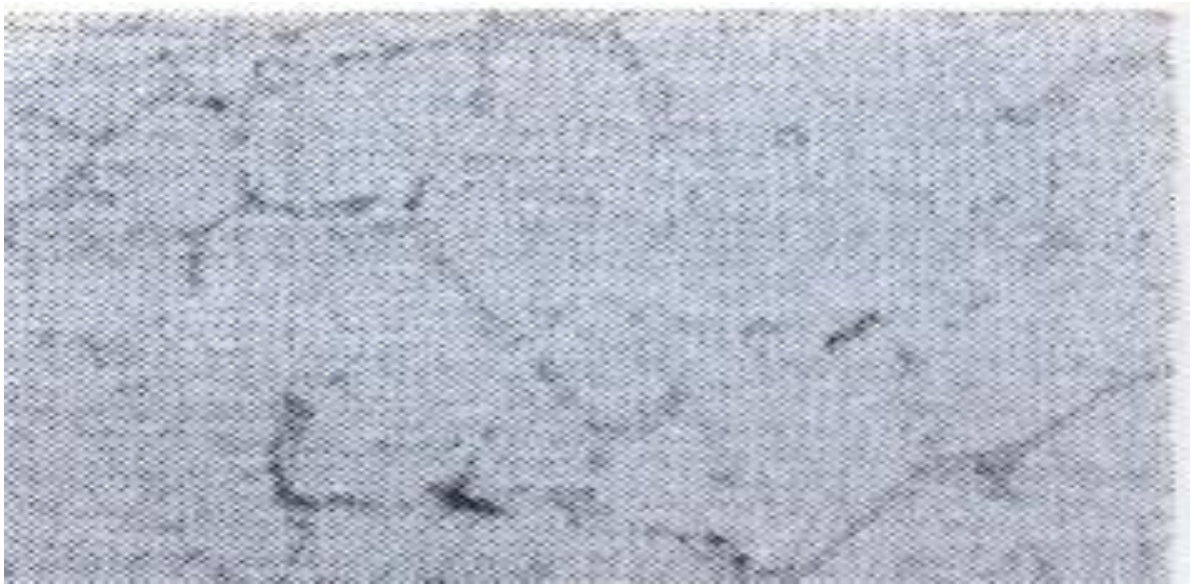

Figure 5. Micrographs of heat treated sample of $\mathrm{Al}_{4} \mathrm{Cu}$ alloy: a) $1 \% \mathrm{Mg}$, b) $2 \% \mathrm{Mg}$, c) $2.5 \% \mathrm{Mg}$

\subsection{Conclusions}

1. Magnesium addition increases the hardness, tensile and yield strength of the alloys in castings but with decrease in ductility of cast alloys.

2. In the range of magnesium additions tried, the sample containing $1.5 \%$ is seems to be a most favourable alloy in terms of tensile strength, yield strength and hardness both in as cast and heat treatment condition.

3. Heat treated Al- Cu-Mg alloys had improved mechanical properties when compared with as-cast alloys.

4. Addition of magnesium to Al-Si alloys beyond $1.5 \% \mathrm{Mg}$ causes decrease for both the strength and hardness of the alloys. However, heat treated samples with composition of $\mathrm{Mg}$ from $0.1-1.5 \%$ have shown an improvement on mechanical properties as compared to as-cast alloys. 


\section{References}

[1] A.Garg and J.M. Howe, (1992): Grain boundary precipitation Al-Cu-Mg-Ag alloy; Journal of acta metarilia, Vol 40

[2] B.Zluticanin, S.Duric, B.Jordovic and B.Radonjic, (2003): Characterization of Microstructure and properties of Al-Cu-Mg alloy $\square$, Journal of mining and metallurgy, Vol 39

[3] D. Apelian (2009): Aluminium cast alloys; Enabling tools for improved performance, North American Die Casting Association, Wheeling, Illinois, USA

[4] Girisha H.N. and K.V.Sharma (2012): Effect of magnesium on strength and microstructure of aluminium copper magnesium alloy, International journal of scientific and engineering research, vol.3, Issue 2.

[5] L.F. Mondolfo, (1976): Aluminium Alloy, Structure and properties, Butterworth and Co ltd, London,

[6] Muhammad Riaz Khan, Irfanullah and Fazal -ur- Rehman (2008): Beneficial effect of heat treatment on mechanical Properties and microstructure of aluminum alloys Used in aerospace industry, j pak mater soc 2008; 2 (1), peshawar, pakistan

[7] V. S. Zolotorevsky, N.A. Belev, M. V. Glazoff (2007): Casting Aluminium Alloys, Mir publishers, Moscow, Pittsburgh, Russia.

[8] William D. Callister, Jr.,(2000): Materials Science and Engineering an Introduction, $6^{\text {th }}$ Edition. John Wiley and Sons, New York. Chap. 10-11. 